DE DE GRUYTER OPEN

\title{
RESPONSE OF TOMATO PLANTS (SOLANUM LYCOPERSICUM) TO STRESS INDUCED BY SB(III)
}

\author{
Matúš Peško, Marianna Molnárová \& Agáta Fargašová \\ Department of Environmental Ecology, Faculty of Natural Sciences, Comenius University in Bratislava, \\ Mlynská dolina, Ilkovičova 6, 84215 Bratislava, Slovak Republic \\ Corresponding author: Agáta Fargašová (e-mail: fargasova@fns.uniba.sk)
}

\begin{abstract}
Presented study evaluates effects of various $\mathrm{Sb}$ (III) concentrations on tomato plants (Solanum lycopersicum) cultivated hydroponically. Visual symptoms of antimony toxicity were observed only at two highest applied concentrations (50 and $100 \mathrm{mg} / \mathrm{L})$. Dry weight of aboveground parts decreased significantly in variants treated with 25,50 and $100 \mathrm{mg} / \mathrm{L} \mathrm{Sb}(\mathrm{III})$, by $\sim 12,35$ and $65 \%$, respectively, in comparison to the control. Statistically significant decrease of chlorophyll $\mathrm{a}$ and $\mathrm{b}$ was observed only after application of two highest studied concentrations 50 and $100 \mathrm{mg} / \mathrm{L} \mathrm{Sb}(\mathrm{III})$. On the other hand concentration of total carotenoids in leaves rose with increasing external $\mathrm{Sb}(\mathrm{III})$ concentration. High concentrations (50 and $100 \mathrm{mg} / \mathrm{L}$ ) of $\mathrm{Sb}$ (III) in nutrient solution caused that protein content in leaves dropped by $\sim 20$ and $39 \%$ relative to control. Accumulation of antimony in roots was about $5-(10 \mathrm{mg} / \mathrm{L})$ to 27 -times $(25 \mathrm{mg} / \mathrm{L})$ greater than that in shoots. The highest BAF factor value determined for shoots was $\sim 55$ at $10 \mathrm{mg} / \mathrm{L} \mathrm{Sb}(\mathrm{III})$ and for roots it was $\sim 821$ at $50 \mathrm{mg} / \mathrm{L} \mathrm{Sb}$ (III). Translocation factor values were in whole studied concentration range $5-100 \mathrm{mg} / \mathrm{L} \mathrm{Sb}(\mathrm{III})<1$. The most effective translocation of antimony from roots to shoots was observes for variants treated with $10 \mathrm{mg} / \mathrm{L} \mathrm{of} \mathrm{Sb}(\mathrm{III})$.
\end{abstract}

Key words: accumulation, antimony, chlorophyll, proteins, Solanum lycopersicum, TBARS

Recommended form of citation: Peško, M., Molnárová, M. \& Fargašová, A., 2016. Response of Tomato Plants (Solanum lycopersicum) to Stress Induced by Sb(III). Acta Environ. Univ. Comenianae (Bratislava). 24(1): 42-47. DOI: 10.1515/aeuc-2016-0006

\section{INTRODUCTION}

Antimony, a metalloid, is widely spread in environment and considered to be highly toxic for various organisms including humans. Even low environmental concentrations can be threatening. The main sources of $\mathrm{Sb}$ are mining sites where the metalloid is released to the environment mainly via oxidative weathering of sulfide minerals (predominantly stibinite $\left(\mathrm{Sb}_{2} \mathrm{~S}_{3}\right)$ ) included in waste products. In Slovakia, such sites are located in vicinity of villages Dúbrava, Medzibrod, Poproč and Čučma (district of Rožňava town). All mines had been closed in 90's but the remained waste could be marked as potentially health risky (HILLER et al. 2012).

The mechanisms of uptake, assimilation, toxicity and detoxification of $\mathrm{Sb}$ in plants are not quite clear as those in animals and humans. The ability of plants to take up Sb depends on these following 
factors: (1) phytoavailability of antimony in soils; (2) speciation of $\mathrm{Sb}$; (3) differences in the concentration of other ions in soils, such as $\mathrm{P}$ and $\mathrm{Ca}$. Uptake of $\mathrm{Sb}$ also varies with plant species (GEBEL 1997; SHTANGEEVA et al. 2011; WAN et al. 2013).

Large amounts of $\mathrm{Sb}$ accumulated in plants can be responsible for various negative effects such as excessive production of reactive oxygen species (ROS), micronutrient uptake retardation, decrease in photosynthesis and synthesis of soluble proteins (DING et al. 2015).

Presented study evaluates effects of Sb(III) on tomato plants (Solanum lycopersicum). Effect on growth (dry mass and length of plants organs) and biochemical (content of photosynthetic pigments, soluble proteins, thiobarbituric acid reactive substances in leaves) parameters of plants were studied. Concentration of $\mathrm{Sb}$ in individual plant parts and corresponding bioaccumulation and translocation factor values were estimated as well.

\section{MATERIAL AND METHODS}

Seeds of Solanum lycopersicum were germinated at $25^{\circ} \mathrm{C}$ for three days in dark on filter paper in Petri dishes filled with $15 \mathrm{~mL}$ of demineralized water. After $72 \mathrm{~h}$ seedlings were transferred to $1 \mathrm{~L}$ beakers filled with Hoagland nutrient solution of $\mathrm{pH}=5.5$ and cultivated in growing chamber at constant conditions for 17 days. After that plants were transferred to nutrient solution with addition of antimony potassium tartrate $\left(\mathrm{K}_{2} \mathrm{Sb}_{2}\left(\mathrm{C}_{4} \mathrm{H}_{2} \mathrm{O}_{6}\right) ; 5,10,25,50,100 \mathrm{mg} / \mathrm{L}\right)$ were they last for another 10 days. All beakers were well aerated by air pump. Conditions in growing chamber were as follows: relative humidity $80 \pm 5 \%$, mean temperature $25 \pm 1{ }^{\circ} \mathrm{C}$, photoperiod: $16 \mathrm{~h}$ light / $8 \mathrm{~h}$ dark, light energy $80 \mu \mathrm{mol} . \mathrm{m}^{-2} . \mathrm{s}^{-1} \mathrm{PAR}$. After 10 days roots and shoots of control plants as well as $\mathrm{Sb}$ (III) treated variants were well dried at $50{ }^{\circ} \mathrm{C}$ in order to determine the dry weight and the content of antimony.

Concentrations of chlorophyll $a, b$ and total carotenoids (chl $a$, chl $b$, carot) in plant leaves were determined spectrophotometrically (chl $a$ at $663.2 \mathrm{~nm}$, chl $b$ at $646.8 \mathrm{~nm}$, and carot at $470.0 \mathrm{~nm}$ ) after extraction into $80 \%(\mathrm{v} / \mathrm{v})$ acetone (Genesys 6, Thermo Scientific, U.S.A) according to LICHTENTHALER (1987). Concentration of thiobarbituric acid reactive substances (TBARS) in leaves of tomato plants was determined according to the method described in detail in PEŠKO et al. (2012). Briefly: $2 \mathrm{~mL}$ of supernatant was incubated at $\sim 95^{\circ} \mathrm{C}$ for 30 min with $1 \mathrm{~mL}$ of mixture containing $0.5 \%(\mathrm{w} / \mathrm{v})$ thiobarbituric acid, $20 \%(\mathrm{v} / \mathrm{v})$ trichloroacetic acid, and $100 \mu \mathrm{L}$ of $4 \%$ butylated hydroxytoluene, followed by cooling in an ice bath for $10 \mathrm{~min}$ and centrifuged $2 \mathrm{~min}$ at $2900 \mathrm{~g}$. The absorbance of the solution was determined at $\lambda=532 \mathrm{~nm}$ spectro-photometrically (Genesis 6 , Thermo Scientific) and concentration of TBARS was calculated using extinction coefficient $\varepsilon=155 \mathrm{~L} / \mathrm{mmol} . \mathrm{cm}$.

Soluble protein concentration in leaves was determined spectrophotometrically (Genesys 6, Thermo Scientific, USA) according to BRADFORD (1976) using Bradford reagent prepared by dissolving of $20 \mathrm{mg}$ Coomassie Brilliant Blue G-250 in $10 \mathrm{~mL}$ of $95 \%$ ethanol, thereafter $20 \mathrm{~mL}$ $\mathrm{H}_{3} \mathrm{PO}_{4}$ and $70 \mathrm{~mL}$ deionized water was added, respectively. The reaction mixture $(200 \mathrm{~L}$ of supernatant and $2 \mathrm{~mL}$ of Bradford reagent) was incubated at room temperature for $5 \mathrm{~min}$. Absorbance of incubated mixture was measured at $\lambda=412 \mathrm{~nm}$ and protein concentration evaluated by using calibration curve. Serum bovine albumin was used as a standard.

Dried plant samples from control and $\mathrm{Sb}(\mathrm{III})$ treatments were digested in solution containing $\mathrm{HNO}_{3}$ and $\mathrm{H}_{2} \mathrm{O}_{2}$ (4:1), than heated in the oven at $160{ }^{\circ} \mathrm{C}$ for $1 \mathrm{~h}$ and diluted with deionized water. Antimony concentration in shoots and roots was determined by means of galvanostatic dissolving chronopotentiometry on EcaFlow 150 GLP (Istran, Slovakia).

The results were evaluated by the multifactorial ANOVA algorithm $(\mathrm{p} \leq 0.05)$ after verification of normality and homogeneity of the variance. 


\section{RESULTS AND DISCUSSION}

Thirty days old tomato plants exposed to different $\mathrm{Sb}(\mathrm{III})$ concentrations for 10 days exhibited visual symptoms of antimony toxicity only at two highest studied concentrations (50 and $100 \mathrm{mg} / \mathrm{L}$ ). Leaves of these plants were chlorotic, wilted and some of them even desiccated. Roots were slightly brownish. Growth of plants treated with $100 \mathrm{mg} / \mathrm{L} \mathrm{Sb}$ (III) was stunt. Slight stimulation of biomass growth (Fig. 1) of plants was observed for variants were $\mathrm{Sb}$ (III) was applied in low concentrations (5 and $10 \mathrm{mg} / \mathrm{L}$ ).

Application of concentrations 25,50 and $100 \mathrm{mg} / \mathrm{L}(\mathrm{Sb}(\mathrm{III})$ ) caused that the dry weight of aboveground parts (leaves + stems) decreased by $\sim 12,35$ and $65 \%$, respectively, in comparison to the control. On the other hand, adverse effect of $\mathrm{Sb}(\mathrm{III})$ on dry weight of roots was observed only in variants treated with $100 \mathrm{mg} / \mathrm{L}$ (Fig. 1). Decrease in root weight of these plants was about $~ 30 \%$, comparing to the untreated variants. Inhibition of plant growth as a result of application of $\mathrm{Sb}$ (III) was observed also in experiments with other species, e.g. paddy rice (DING et al. 2015), fern plants (FENG et al. 2009), maize (PAN et al. 2011), and lichen (PAOLI et al. 2013).

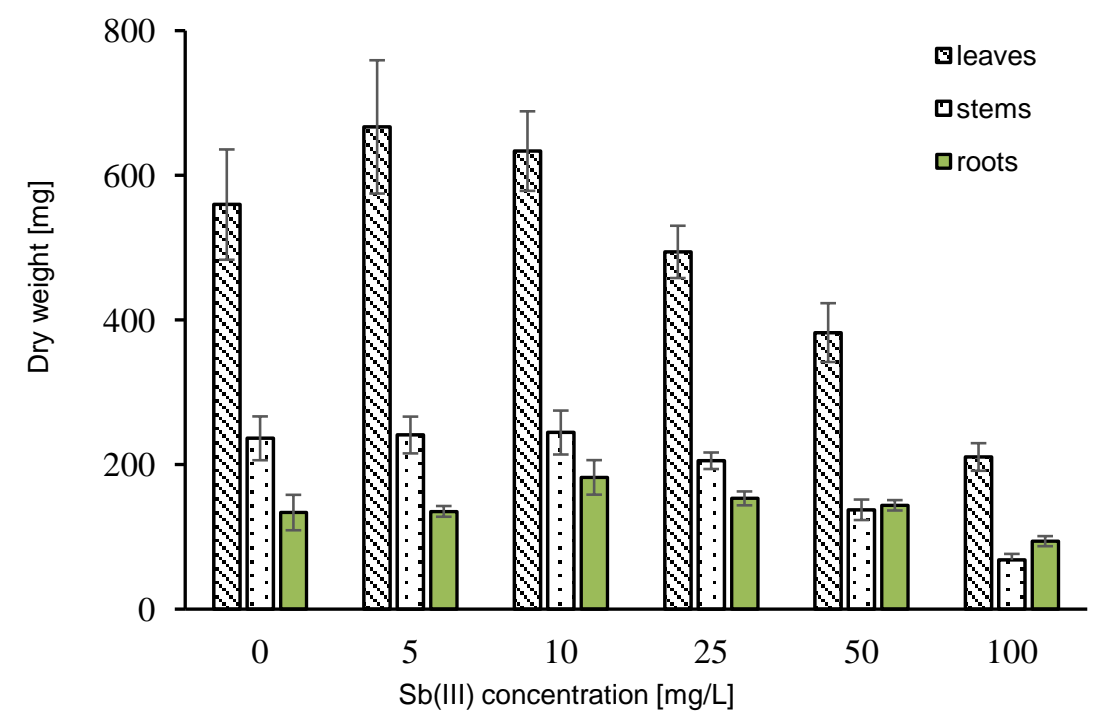

Fig. 1: Dependence of dry weight of leaves, stems and roots of tomato plants on different $\mathrm{Sb}(\mathrm{III})$ concentrations. Mean \pm S.E.; $n=5$; S.E. - standard error

Relationship between external concentration of antimony potassium tartrate and concentration of photosynthetic pigments in leaves of tomato plants is shown in Fig. 2. Statistically significant decrease of chlorophyll $a$ and $b$ was observed only after application of two highest studied concentrations 50 and $100 \mathrm{mg} / \mathrm{L} \mathrm{Sb}$ (III). Comparing to the control plants, chlorophyll $a$ dropped by $\sim 31$ and $55 \%$, and chlorophyll $b$ by $\sim 39$ and $\sim 59 \%$, respectively. Similar results were observed also by PAN et al. (2011) in their experiments with Zea mays plants. This suggest that $\mathrm{Sb}$ is interfering with biomolecules involved in synthesis of chlorophylls. Antimony could also interfere with or damage important molecules and enzymes within chloroplasts, which is supported by results from experiments of DING et al. (2015). They found that more than $10 \%$ of $\mathrm{Sb}$ accumulated in shoots of paddy rice plants was located in chloroplasts. Concentration of total carotenoids in leaves rose with increasing concentration of $\mathrm{Sb}$ (III) in nutrient solution. Application of $100 \mathrm{mg} / \mathrm{L} \mathrm{Sb}$ (III) caused that concentration of total carotenoids was almost twice the control. Excessive production of carotenoids is probably a part of protection mechanism against oxidative stress. 


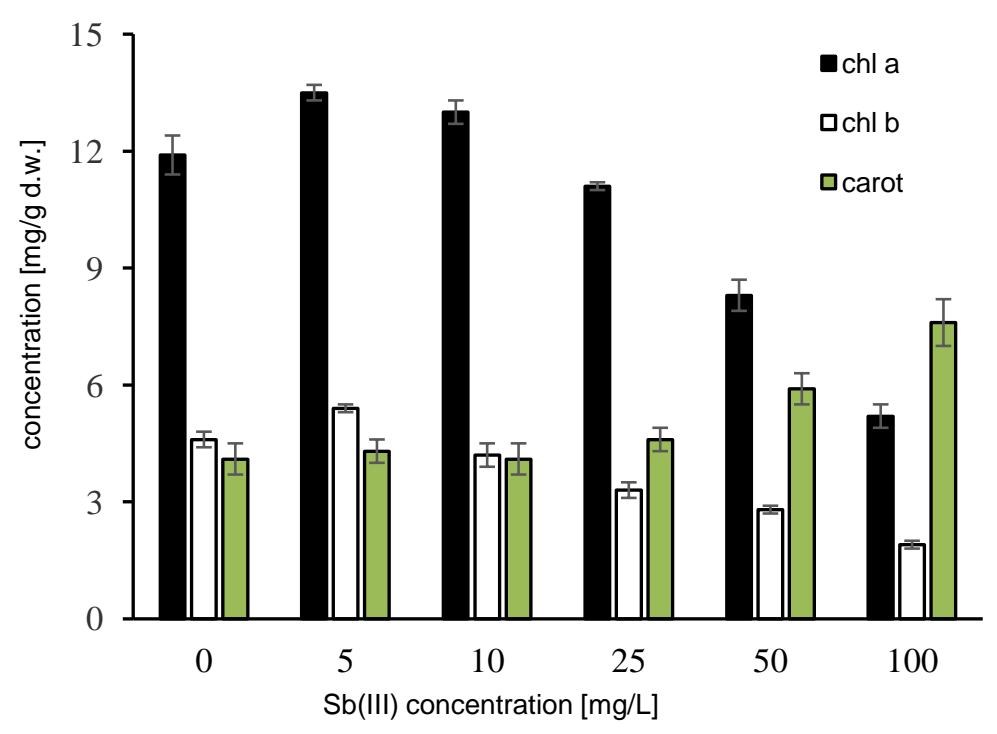

Fig. 2: Dependence of chlorophyll $a$ (chl a) and $b(\mathrm{chl} \mathrm{b})$ as well as carotenoids (carot) concentration in leaves of tomato plants on different $\mathrm{Sb}(\mathrm{III})$ concentrations. Mean \pm S.E.; $\mathrm{n}=5$; S.E. - standard error; d.w. dry weight

Concentration of TBARS and soluble proteins in leaves of plants treated with different concentrations of $\mathrm{Sb}(\mathrm{III})$ are summarized in Tab. 1. In our study concentration of these products (Tab. 1) in leaves of tomato plants rose as the external concentration of $\mathrm{Sb}$ (III) increased. Massive accumulation of TBARS in leaves was observed for variants treated with two highest studied concentrations (50 and $100 \mathrm{mg} / \mathrm{L} \mathrm{Sb}(\mathrm{III})$ ). Accumulation of these products reached $\sim 129$ and $240 \%$ of control. Thiobarbituric acid reactive substances (TBARS), products of peroxidation of membrane lipids, are very good marker of oxidative stress caused by the presence of metals. Our results are in good conformity with experiments of many other authors. For example accumulation of TBARS in shoots of Hedysarum pallidum plants grown on highly contaminated Sb-mining sites was 5-times greater than in those grown on uncontaminated control sites (BENHAMDI et al. 2014).

High concentrations (50 and $100 \mathrm{mg} / \mathrm{L}$ ) of $\mathrm{Sb}$ (III) in nutrient solution caused that protein concentration in leaves dropped by $\sim 20$ and $39 \%$ relative to the control. Reactive oxygen species (ROS) that are produced as a result of oxidative stress, are responsible not only for membrane lipid peroxidation but cause protein inactivation and degradation as well. The bulk of the oxidized proteins is then degraded by proteolysis (SHRINGARPURE et al. 2003).

Tab. 1: Concentration of TBARS and soluble proteins in leaves of tomato plants treated with different concentrations of $\mathrm{Sb}(\mathrm{III})$

\begin{tabular}{ccc}
\hline $\mathbf{c}$ Sb(III) & TBARS & $\begin{array}{c}\text { Soluble proteins } \\
\text { [mg/g d.w.] }\end{array}$ \\
\hline $\mathbf{m g} / \mathbf{L}]$ & {$[\boldsymbol{\mu m o l} / \mathbf{g}$ d.w.] } & $41.4 \pm 2.1$ \\
$\mathbf{5}$ & $1.7 \pm 0.10$ & $43.3 \pm 2.0$ \\
$\mathbf{1 0}$ & $2.3 \pm 0.10$ & $42.2 \pm 1.6$ \\
$\mathbf{2 5}$ & $2.2 \pm 0.05$ & $40.4 \pm 3.1$ \\
$\mathbf{5 0}$ & $2.6 \pm 0.11$ & $33.3 \pm 2.9$ \\
$\mathbf{1 0 0}$ & $3.9 \pm 0.12$ & $26.1 \pm 2.3$ \\
\hline
\end{tabular}


Concentration of $\mathrm{Sb}$ in roots and shoots increased with increasing external $\mathrm{Sb}$ (III) concentration. Accumulation of antimony in roots was about $5-(10 \mathrm{mg} / \mathrm{L})$ to 27 -times $(25 \mathrm{mg} / \mathrm{L})$ greater than that in shoots. The fact that tomato plants were able to accumulate in their shoots more than $10 \mu \mathrm{g} \mathrm{Sb} / \mathrm{g}$ d.w. already at the lowest applied external concentration, $5 \mathrm{mg} / \mathrm{L} \mathrm{Sb}(\mathrm{III})$, suggests that Solanum lycopersicum is Sb-tolerant. But it can't be marked as an accumulator of this metalloid because most of $\mathrm{Sb}$ remained accumulated in roots. Higher amount of Sb accumulated in shoots was observed by HAMMEL et al. (2000). Spinach plants grown on contaminated soil (100 $\mu \mathrm{g} \mathrm{Sb}(\mathrm{III}) / \mathrm{g}$ ) were able to accumulate $399 \mu \mathrm{g} \mathrm{Sb} / \mathrm{g}$ d.w. in shoots.

Tab. 2: Concentration of antimony in shoots and roots as well as corresponding bioaccumulation factor (BAF) and translocation factor $(\mathrm{TF})$ values, and percentage share of $\mathrm{Sb}$ accumulated in shoots of tomato plants treated with different $\mathrm{Sb}(\mathrm{III})$ concentrations

\begin{tabular}{ccccccc}
\hline \multirow{2}{*}{$\mathbf{c ~ S b}(\mathbf{I I I}) \mathbf{~ m g / L}$} & \multicolumn{2}{c}{$\mathbf{c ~ S b}[\boldsymbol{\mu g} / \mathbf{g}$ d.w.] } & \multicolumn{2}{c}{ BAF } & TF & $\begin{array}{c}\text { \% of Sb } \\
\text { in shoots }\end{array}$ \\
& Shoots & Roots & Shoots & Roots & & 19.0 \\
$\mathbf{5}$ & 43.9 & 688.6 & 46.2 & 577.7 & 0.064 & 26.8 \\
$\mathbf{1 0}$ & 105.1 & 548.8 & 55.3 & 362.4 & 0.192 & 6.8 \\
$\mathbf{2 5}$ & 132.3 & 3612.5 & 27.8 & 760.5 & 0.037 & 7.4 \\
$\mathbf{5 0}$ & 308.1 & 7798.6 & 32.4 & 820.9 & 0.040 & 9.2 \\
$\mathbf{1 0 0}$ & 998.5 & 13162.9 & 54.8 & 692.8 & 0.090 & \\
\hline
\end{tabular}

The highest BAF factor value determined for shoots was $\sim 55$ at $10 \mathrm{mg} / \mathrm{L} \mathrm{Sb}$ (III) and for roots it was $\sim 821$ at $50 \mathrm{mg} / \mathrm{L} \mathrm{Sb}(\mathrm{III})$. This suggests that bioaccumulation of antimony within aboveground parts is most effective at lower external concentrations.

Translocation factor values were in whole studied concentration range $5-100 \mathrm{mg} / \mathrm{L} \mathrm{Sb}$ (III) < 1 , suggesting restricted translocation of $\mathrm{Sb}$ into the aboveground parts. The most effective translocation of antimony from roots to shoots was observed for variants treated with $10 \mathrm{mg} / \mathrm{L}$ of $\mathrm{Sb}(\mathrm{III})$. TF value was in this case 0.192 .

The amount of antimony accumulated in shoots depends not only on applied external concentration but also on dry weight of plant organs. The percentage share of Sb accumulated in shoots from total amount accumulated by tomato plants was for low external concentrations relatively high, 19\% $(5 \mathrm{mg} / \mathrm{L})$ and $26.8 \%(10 \mathrm{mg} / \mathrm{L})$. In case of variants treated with higher concentrations, the percentage share was below $10 \%$.

\section{CONCLUSION}

According to the presented results it can be said that toxic effects of antimony on tomato plants (Solanum lycopersicum) were exhibited only in variants treated with higher concentrations (50 and $100 \mathrm{mg} / \mathrm{L}$ ) of studied metalloid. These variants exhibited moderate to severe signs of Sb toxicity, including chlorosis, stunt plant growth, decreased concentration of chlorophylls, soluble proteins, and increased accumulation of products of lipid peroxidation in leaves, nevertheless Solanum lycopersicum could be marked as Sb-tolerant because in presence of lower $\mathrm{Sb}$ (III) concentrations (5, 10 and $25 \mathrm{mg} / \mathrm{L}$ ) was the accumulation of antimony in aboveground parts relatively high, which in turn could be utilized in phytoremediation of lightly to moderate polluted sites, but further field experiments should be done to support our results. 


\section{ACKNOWLEDGEMENTS}

This work was funded by the grant of Ministry of Education, Science, Research and Sport of the Slovak Republic VEGA 1/0098/14 and this contribution is also result of the project implementation ITMS 26240120014 "Center of excellence for protection and use of landscape and for biodiversity" supported by the ERDF.

\section{REFERENCES}

Benhamdi A., Bentellis A., Rached O., Du Laing G. \& MechakRa A. 2014. Effects of antimony and arsenic on antioxidant enzyme activities of two steppic plant species in an old antimony mining area. Biol. Trace. Elem. Res. 158: 96-104.

BRADFORD M.M. 1976. Rapid and sensitive method for the quantitation of microgram quantities of protein utilizing the principle of protein-dye binding. Anal. Biochem. 72: 248-254.

Ding Y., WANG R., GuO J., WU F., XU Y. \& FENG R. 2015. The effect of selenium on the subcellular distribution of antimony to regulate the toxicity of antimony in paddy rice. Environ. Sci. Pollut. Res. Int. 22(7): 51115123.

FENG R. W., WeI C. Y., TU S. X., WU F. C. \& YANG L. S. 2009. Antimony accumulation and antioxidative responses in four fern plants. Plant Soil 317: 93-101.

GEBEL T. 1997. Arsenic and antimony: comparative approach on mechanistic toxi-cology. Chem. Biol. Interact. 107: 131-144.

Hammel W., Debus R. \& Steubing L. 2000. Mobility of antimony in soil and its avail-ability to plants. Chemosphere 41: 1791-1798.

Hiller E., Lalinská B., Chovan M., Jurkovič L., Klimko T., Jankular M., Hovorič R., ŠOtTnik P., FLAKOVÁ R., ŽENIŠOVÁ Z. \& ONDREJKOVÁ I. 2012. Arsenic and antimony contamination of waters, stream sediments and soils in the vicinity of abandoned antimony mines in the Western Carpathians, Slovakia. Appl. Geochem. 27: 598-614.

LICHTENTHALER H. K. 1987. Chlorophylls and carotenoids: Pigments of photosynthetic biomembranes. Method. Enzymol. 148: 350-382.

PAN X., ZhANG D., Chen X., BAO A. \& Li L. 2011. Antimony accumulation, growth performance, antioxidant defense system and photosynthesis of Zea mays in response to antimony pollution in soil. Water Air Soil Pollut. 215: 517-523.

PaOli L., Fiorini E., MunZi S., Sorbo S., BaSiLe A. \& LoPPI S. 2013. Antimony toxicity in the lichen Xanthoria parietina (L.) Th. Fr. Chemosphere 93: 2269-2275.

PeŠKo M., KRÁLOVÁ K. \& BlaŠKO J. 2012. Phytotoxic effects of trivalent chromium on rapeseed plants. Fresen. Environ. Bull. 21(3A): 761-768.

Shringarpure R., Grune T., Mehlhase J. \& DaVIES K. J. A. 2003. Ubiquitin conjugation is not required for the degradation of oxidized proteins by proteasome. J. Biol. Chem. 278: 311-318.

SHTANGeEVA I., BALI R. \& HARRIS A., 2011. Bioavailability and toxicity of antimony. J. Geochem. Explor. 110: 40-45.

Wan X. M., Tandy S., Hockmann K. \& SChUlin R. 2013. Changes in Sb speciation with waterlogging of shooting range soils and impacts on plant uptake. Environ. Pollut. 172: 53-60. 